\title{
Analisis Faktor-Faktor yang Mempengaruhi Pemahaman Konsep Matematis Mahasiswa dalam Pembelajaran Jarak Jauh Pada Masa Pandemi Covid-19
}

\author{
Sofia Debi Puspa ${ }^{1}$, Joko Riyono ${ }^{2}$, Fani Puspitasari ${ }^{3}$ \\ 1,2 Program Studi Teknik Mesin, Fakultas Teknologi Industri, Universitas Trisakti, \\ ${ }^{3}$ Program Studi Teknik Industri, Fakultas Teknologi Industri, Universitas Trisakti, \\ Jl. Kyai Tapa No.1 Grogol, Jakarta Barat, Indonesia \\ Sofia.debi.puspa@trisakti.ac.id
}

\begin{abstract}
The study aims to determine the factors that have a significant effect on students' ability to understand mathematical concepts in online learning during the covid-19 pandemic. The factors referred to intrinsic factor and extrinsic factor. The intrinsic factor is students' motivation, while extrinsic factors are the role of lecturers, facilities and family environment. This research using quantitive study and primary data from a survey. The software used in data processing are R-Studio and SPSS Statistics. The stages of this research are data collection, instrument test by using validity and reliability test, classic assumption test (normality test, multicollinearity test, heteroscedasticity test, autocorrelation test), multiple linear regression analysis, F-test and t-test. The results showed that the variables of motivation, the role of lecturers, facilities and family environment had a significant effect simultaneously and partially significant influence on students' ability to understand mathematical concepts in online learning. The R-Square value obtained from the model is $74 \%$, which means that there is strong influence on the variables of motivation, the role of lecturers, facilities and the family environment in influencing students' understanding of mathematical concepts. The multiple linear regression analysis model obtained is:
\end{abstract}

$$
\widehat{Y}=0.1833+0.7746 X_{1}+0.1443 X_{2}+0.0882 X_{3}+0.0768 X_{4}
$$

Keywords: Understanding of Mathematical Concepts; Multiple Regression Analysis; Online Learning

\begin{abstract}
Abstrak
Penelitian ini bertujuan untuk mengetahui faktor-faktor yang berpengaruh signifikan terhadap kemampuan pemahaman konsep matematis mahasiswa dalam pembelajaran jarak jauh pada masa pandemi covid-19. Faktor yang dimaksud adalah faktor intrinsik dan faktor ekstrinsik. Faktor intrinsik yaitu motivasi belajar mahasiswa, sedangkan faktor ekstrinsik yaitu peran dosen, fasilitas dan lingkungan keluarga. Jenis penelitian ini merupakan penelitian kuantitatif dan menggunakan data primer dari kuesioner. Aplikasi perangkat lunak yang digunakan dalam mengolah data adalah $R$-Studio berbasis open source dan SPSS Statistics. Tahapan dari penelitian ini yaitu pengumpulan data, uji instrumen dengan uji validitas dan reliabilitas, uji asumsi klasik (uji normalitas, uji multikolinearitas, uji heteroskedastisitas, uji autokorelasi), analisis regresi linear berganda, uji $\mathrm{F}$ dan uji-t. Hasil penelitian menunjukkan bahwa variabel motivasi, peran dosen, fasilitas dan lingkungan keluarga berpengaruh signifikan secara simultan (bersama-sama) dan berpengaruh signifikan secara parsial terhadap kemampuan pemahaman konsep matematis mahasiswa dalam pembelajaran jarak jauh. Nilai $\mathrm{R}$ Square yang diperoleh dari model adalah sebesar $74 \%$ yang artinya terdapat hubungan pengaruh yang kuat pada variabel motivasi, peran dosen, fasilitas dan lingkungan keluarga dalam mempengaruhi pemahaman konsep matematis mahasiswa. Model analisis regresi linear berganda yang dihasilkan yaitu:
\end{abstract}

$$
\hat{Y}=0.1833+0.7746 X_{1}+0.1443 X_{2}+0.0882 X_{3}+0.0768 X_{4}
$$

Kata kunci: Pemahaman Konsep Matematis, Analisis Regresi Berganda, Pembelajaran Jarak Jauh

Copyright (c) 2021 Sofia Debi Puspa

$\triangle$ Corresponding author: Sofia Debi Puspa

Email Address: sofia.debi.puspa@trisakti.ac.id

Received 20 Februari 2021, Accepted 27 Februari 2021, Published 03 Maret 2021

\section{PENDAHULUAN}

Pandemi covid-19 yang terjadi di Indonesia sejak tahun 2020 berdampak pada berbagai bidang dan sektor. Selain itu, pandemi tersebut juga mengubah pola hidup masyarakat agar mampu 
menghentikan penyebaran virus, diantaranya yaitu mengurangi interaksi bertemu langsung dengan orang lain, melakukan physical distancing dan mematuhi protokol kesehatan. Kebiasaan baru tersebut tidak hanya berdampak pada bidang ekonomi dan kesehatan, namun juga pada bidang pendidikan pun memiliki penyesuaian dalam proses pembelajaran.

Berdasarkan Surat Edaran Menteri Pendidikan dan Kebudayaan Nomor 4 Tahun 2020 tentang Pelaksanaan Kebijakan Pendidikan bahwa satuan pendidikan yang berada di daerah zona kuning, oranye dan merah dilarang melakukan proses pembelajaran tatap muka di satuan pendidikan dan tetap melanjutkan Belajar dari Rumah (Kementerian Pendidikan dan Kebudayaan Republik Indonesia, 2020). Dengan adanya kondisi pandemi tidak memungkinkan untuk melaksanakan pembelajaran tatap muka secara normal, namun diperlukan Pembelajaran Jarak Jauh (PJJ) atau disebut pembelajaran daring.

Pembelajaran daring merupakan pembelajaran dengan bentuk penyampaian yang dituangkan pada format digital dan memanfaatkan perangkat elektronik khususnya menggunakan jaringan internet dengan fleksibilitas, konektivitas, aksesibilitas dan kemampuan untuk mencapai berbagai interaksi pembelajaran (Moore, Dickson-Deane dan Galyen, 2011). PJJ mengubah gaya belajar peserta didik serta mengubah model pembelajaran yang diterapkan oleh pendidik ke peserta didik. Guru atau dosen sebagai pendidik sangat perlu untuk memiliki kemampuan komunikasi yang jelas dan baik, kemampuan dalam menyusun materi dalam pengorganisasian pembelajaran serta kemampuan dalam mengolah media pembelajaran yang digunakan agar tidak terjadi miskonsepsi antara dosen dengan mahasiswa selaku peserta didik.

Dalam penelitian yang dilakukan oleh Sadikin bahwa pembelajaran daring efektif untuk mengatasi pembelajaran yang memungkinkan dosen dan mahasiswa berinteraksi dalam kelas virtual yang dapat diakses dimana saja dan kapan saja dibutuhkan. Namun terdapat kekurangan dalam pembelajaran daring yaitu kurangnya pengawasan secara langsung dalam proses pembelajaran sehingga hal ini dapat mempengaruhi keefektifan pembelajaran daring. Selain itu, fasilitas seperti lemahnya sinyal dan mahalnya biaya kuota menjadi tantangan dalam pembelajaran daring (Sadikin dan Hamidah, 2020). Perubahan pembelajaran dari tatap muka menjadi daring secara mendadak memunculkan berbagai respon. Purwanto mengemukakan bahwa terdapat kendala yaitu peserta didik belum memiliki budaya belajar jarak jauh sehingga perlu waktu untuk beradaptasi dalam menghadapi perubahan baru yang secara tidak langsung mempengaruhi daya serap belajar peserta didik. Selain itu, terdapat dosen/guru yang kurang mahir dalam menggunakan teknologi sebagai sarana pembelajaran (Purwanto, et.al, 2020).

Seiring dengan perubahan lingkungan belajar juga terdapat banyak faktor yang akan mempengaruhi peserta didik atau mahasiswa dalam memahami pelajaran, utamanya pada pelajaran yang berkaitan dengan matematika. Karena dalam mempelajari matematika, peserta didik perlu mengonstruksi pengetahuan dalam memahami konsep-konsep matematis yang diajarkan serta mengkomunikasikan ide-idenya dalam bentuk lisan maupun tulisan (Kusuma, 2016). Menurut 
Depdiknas (2006) bahwa salah satu kemampuan matematis yang penting untuk dimiliki oleh mahasiswa selaku peserta didik adalah pemahaman konsep matematis. Selain itu pemahaman konsep matematis adalah hal penting dalam prinsip pembelajaran matematika (NCTM, 2000). Pemahaman konsep matematis adalah kemampuan peserta didik dalam mendefinisikan, mengelompokkan, memberi contoh, menghubungkan serta mengembangkan suatu konsep dari apa yang telah dipelajari dengan pengetahuan baru serta mampu membuat aloritma dari suatu konsep (Hendriana, et.al., 2017). Pemahaman konsep matematis sangat penting dimiliki oleh mahasiswa dengan jurusan yang berkaitan dengan Matematika \& Ilmu Pengetahuan Alam (MIPA) karena selain memudahkan belajar matematika, konsep-konsep dalam matematika terorganisasikan secara sistematis dari yang paling sederhana ke yang paling kompleks.

Oleh karena itu, berdasarkan latar belakang yang telah dipaparkan di atas maka penelitian ini mengkaji tentang analisis faktor-faktor yang mempengaruhi pemahaman konsep matematis mahasiswa dalam pembelajaran jarak jauh pada masa pandemi covid-19. Dalam penelitian ini, analisa statistik yang digunakan untuk menentukan faktor-faktor yang berpengaruh signifikan adalah dengan menggunakan analisa regresi linear berganda. Pada analisa regresi linear berganda membahas pola hubungan beberapa variabel bebas (variabel independent) terhadap variabel tidak bebas (variabel dependent). Penelitian ini akan memberikan gambaran informasi pembelajaran jarak jauh pada masa pandemi covid-19 serta indikator-indikator apa saja yang sangat mempengaruhi pemahaman konsep matematis mahasiswa dalam PJJ sehingga dapat dilakukan evaluasi dalam menyusun perencanaan pembelajaran selanjutnya dengan model pembelajaran yang efektif.

\section{METODE}

Penelitian ini dilaksanakan pada bulan November 2020 sampai dengan Januari 2021. Jenis penelitian ini merupakan penelitian kuantitatif dan menggunakan data primer dari kuesioner yang dilakukan secara daring. Teknik pengumpulan data yaitu dengan menggunakan kuesioner yang berisi sejumlah pertanyaan-pertanyaan. Aplikasi perangkat lunak yang digunakan dalam mengolah data penelitian ini adalah $R$ statistical computing berbasis open source dan SPSS Statistics. Berikut ini ditampilkan diagram alir (flowchart) dari tahap penelitian pada Gambar 1.

Populasi pada penelitian ini adalah mahasiswa yang telah mengikuti perkuliahan semester gasal tahun ajaran 2020/2021 dari Perguruan Tinggi Negeri/Swasta di Jabodetabek. Sampel penelitian ini berjumlah 262 orang. Pemahaman konsep yang dinilai adalah pemahaman konsep yang berkaitan dengan ilmu matematika seperti mata kuliah kalkulus, aljabar linear, statistika, matematika teknik, matematika optimasi dan sejenisnya, sehingga responden adalah mahasiswa yang mengambil mata kuliah terkait matematis agar masalah lebih terfokus.

Variabel independent (variabel bebas) dalam penelitian ini adalah motivasi belajar, peran dosen, fasilitas dan lingkungan keluarga, sedangkan variabel dependent (variabel terikat) dalam penelitian ini adalah pemahaman konsep matematis mahasiswa. Analisa statistik yang digunakan 
untuk menentukan faktor-faktor yang berpengaruh signifikan adalah dengan menggunakan analisa regresi linear berganda. Tahapan pada penelitian ini adalah uji validitas, uji reliabilitas, uji asumsi klasik dan analisis regresi berganda.

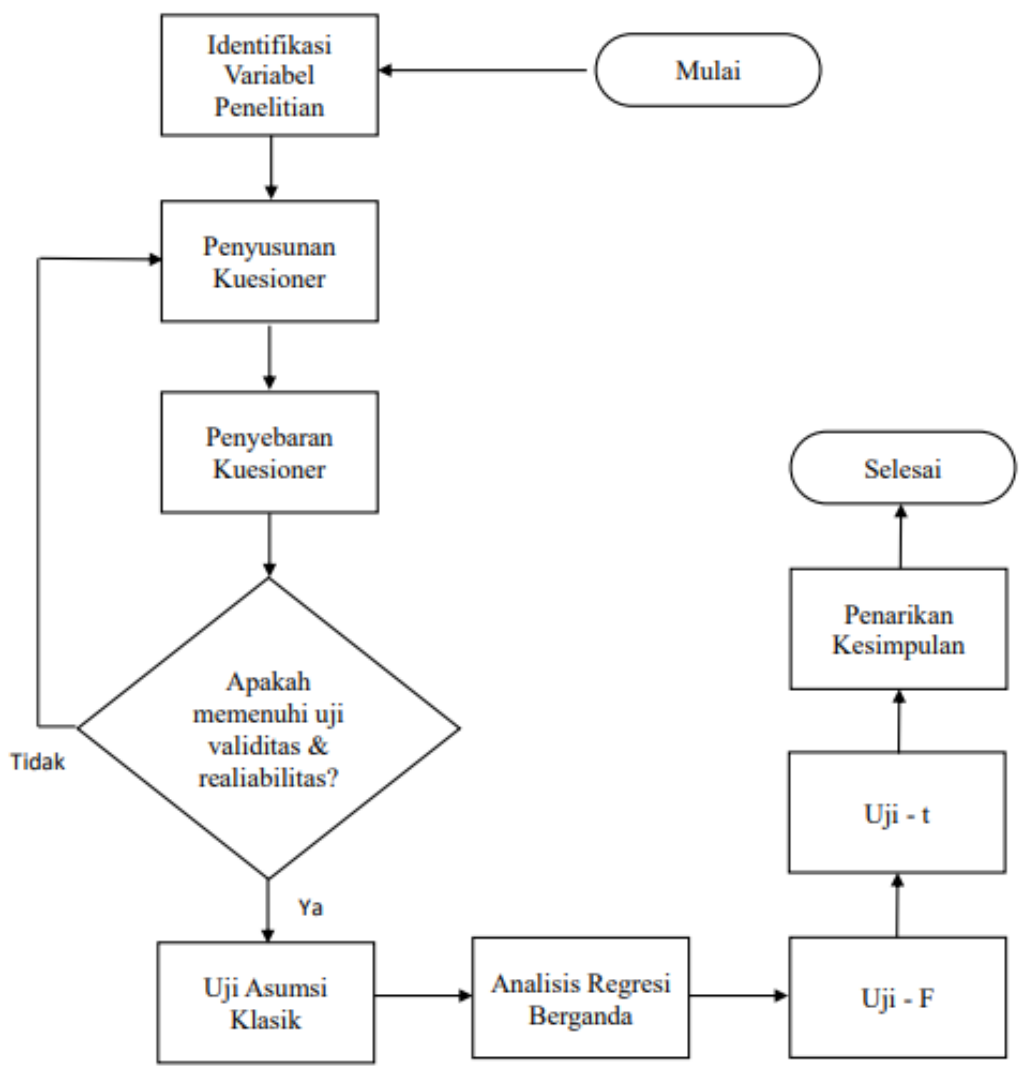

Gambar 1. Diagram Alir Penelitian

\section{Uji Validitas}

Uji validitas adalah suatu uji yang digunakan untuk mengetahui kesahihan atau tidaknya suatu kuesioner. Kuesioner dikatakan sahih atau valid jika pertanyaan pada kuesioner mampu mewakili sesuatu yang akan diukur pada kuesioner. Uji validitas dalam penelitian ini menggunakan rumus korelasi Pearson Product Moment yang ditunjukkan pada persamaan (1):

$$
r_{x y}=\frac{N \sum X Y-\left(\sum X\right)\left(\sum Y\right)}{\sqrt{\left\{N \sum X^{2}-\left(\sum X\right)^{2}\right\}\left\{N \sum Y^{2}-\left(\sum Y\right)^{2}\right\}}}
$$

Pengambilan keputusan setiap item pada uji validitas adalah sebagai berikut (Ghozali, 2011):

a. Jika $r_{\text {hitung }} \geq r_{\text {tabel }}$ maka instrumen tersebut dianggap valid

b. Jika $r_{\text {hitung }}<r_{\text {tabel }}$ maka instrumen tersebut dianggap tidak valid

\section{Uji Reliabilitas}

Reliabilitas adalah derajat ketelitian atau keakuratan yang dimiliki oleh instrumen pengukuran. Uji reliabilitas menggunakan rumus Cronbach's Alpha yang ditunjukkan pada persamaan (2): 


$$
A=\frac{K \cdot r}{1+(K-1) \cdot r}
$$

Keterangan:

$A:$ Koefisien reliabilitas

$K:$ Jumlah item reliabilitas

$r$ : Rata-rata korelasi antar item

Pengambilan keputusan pada uji reliabilitas adalah sebagai berikut (Umar, 2007):

a. Jika koefisien reliabilitas $\geq 0.6$ maka item memiliki reliabilitas yang baik

b. Jika koefisien reliabilitas $<0.6$ maka item memiliki reliabilitas yang kurang baik

\section{Uji Asumsi Klasik}

a. Uji Normalitas

Uji Normalitas adalah untuk mengetahui apakah varibel dependen dan variabel independen berdistribusi normal. Pengujian normalitas salah satunya menggunakan normal probability plot atau dengan melihat histogram yang membandingkan antara data observasi dengan distribusi yang medekati distribusi normal (Ghozali, 2011). Selain itu uji normalitas juga dapat dianalisis dengan menggunakan Uji Normalitas Kolmogorov-Smirnov dengan dasar pengambilan keputusan yaitu sebagai berikut:

i. Jika nilai signifikansi (Sig.) lebih besar dari 0.05 maka data terdistribusi normal

ii. Jika nilai signifikansi (Sig.) lebih kecil dari 0.05 maka data tidak terdistribusi normal

\section{b. Uji Multikolinearitas}

Uji multikolinearitas adalah untuk menguji apakah di dalam model regresi ditemukan adanya korelasi antar variabel bebas (independen). Model regresi yang baik seharusnya tidak memiliki korelasi antar variabel independen. Untuk mendeteksi adanya multikolinearitas adalah dengan menggunakan nilai Tolerance dan Variance Inflation Factor (VIF). Berikut merupakan pedoman keputusannya:

Pedoman Keputusan Berdasarkan Nilai Tolerance

i. Jika nilai tolerance lebih besar dari 0,10 maka tidak terjadi multikolinearitas dalam model regresi

ii. Jika nilai tolerance lebih kecil dari 0,10 maka terjadi multikolinearitas dalam model regresi

Pedoman Keputusan Berdasarkan Nilai Variance Inflation Factor (VIF)

i. Jika nilai VIF $<10,00$ maka tidak terjadi multikolinearitas dalam model regresi

ii. Jika nilai VIF > 10,00 maka terjadi multikolinearitas dalam model regresi 
c. Uji Heteroskedastisitas

Uji heteroskedastisitas adalah untuk mengetahui apakah di dalam model regresi terjadi ketidaksamaan variance dari residual satu pengamatan ke pengamatan lain. Model regresi yang bersifat homoskedastisitas dimana residual antar suatu pengamatan ke pengamatan lainnya tetap merupakan model regresi yang baik. Atau dengan kata lain regresi yang baik seharusnya tidak terjadi heteroskedastisitas (Suharjo, 2008). Berikut ini merupakan kriterianya:

i. Jika terjadi pola tertentu, seperti titik-titik yang membentuk pola teratur (bergelombang, melebar kemudian menyempit), maka terjadi heteroskedastisitas.

ii. Jika tidak ada pola yang jelas, serta titik-titik tersebut menyebar di atas dan di bawah angka 0 pada sumbu Y, maka terjadi homoskedastisitas.

\section{d. Uji Autokorelasi}

Uji autokorelasi adalah untuk menguji apakah dalam model regresi linear terdapat korelasi antara kesalahan pengganngu pada periode $t$ dengan kesalahan pengganggu pada periode $t-1$ (sebelumnya). Pengujian adanya autokorelasi dalam suatu model regresi dilakukan dengan menggunakan Statistik $d$ Durbin-Watson (The Durbin-Watson $d$ Statistics) yang ditunjukkan pada persamaan (3) di bawah ini (Supranto, 2016):

$$
d=\frac{\sum_{i=2}^{n}\left(e_{i}-e_{i-1}\right)^{2}}{\sum_{i=1}^{n} e_{i}^{2}}
$$

dimana:

$d=$ Durbin Watson

$e_{t} \quad=$ nilai residu dari persamaan regresi periode $t$

$e_{t-1}=$ nilai residu dari persamaan regresi periode $t-1$

Berikut merupakan kriteria pengujiannya:

$H_{0}$ : tak ada korelasi serial (autokorelasi) yang positif

$H_{a}$ : ada korelasi serial (autokorelasi) yang positif

\section{Analisis Regresi Berganda}

Regresi Linear Berganda adalah suatu metode statistik yang digunakan untuk mengetahui hubungan pengaruh antara sebuah variabel tidak bebas/dependent variable terhadap variabel bebas/independent variable (Ghozali, 2011). Untuk keperluan analisis, variabel bebas dinyatakan dengan $X$ sedangkan variabel tidak bebas dinyatakan dengan $Y$. Persamaan (4) merupakan model regresi linear berganda: 


$$
Y=\beta_{0}+\beta_{1} X_{1}+\beta_{2} X_{2}+\cdots+\beta_{n} X_{n}+\varepsilon_{i}
$$

dimana:

$Y=$ Variabel tak bebas (dependent)

$\beta_{0}=$ konstanta

$\beta_{i}=$ koefisien slope (kemiringan) dari variabel atau atribut ke- $\mathrm{i}$

$X_{i j}=$ variabel bebas prediktor ke-j dari responden ke-i, disebut juga atribut

$\varepsilon_{i}=$ error (kesalahan pengganggu)

\section{Uji F Pada Regresi Linear Berganda}

Uji F digunakan untuk mengetahui seberapa berpengaruh variabel independen terhadap variabel dependen secara bersama-sama dalam sebuah model regresi. Pada persamaan (5) diberikan rumus $F_{0}$ dalam menguji model

$$
F_{0}=\frac{R^{2} / k}{\left(1-R^{2}\right) /(n-k-1)}
$$

Hipotesis yang akan diuji adalah:

$H_{0}: \beta_{1}=\beta_{2}=\cdots=\beta_{j}=\beta_{k}=0$

(tidak ada pengaruh dari $X_{1}, X_{2}, \ldots, X_{j}, \ldots, X_{k}$ terhadap $Y$

$H_{a}: \beta_{j} \neq 0$

(paling sedikit ada satu variabel $X$ yang mempengaruhi $Y$, misalnya $X_{j} \rightarrow \beta_{j} \neq 0$

Kriteria pengambilan keputusan adalah sebagai berikut:

i. Jika $F_{0} \geq F_{\text {tabel }}$ maka $H_{0}$ ditolak

ii. Jika $F_{0}<F_{\text {tabel }}$ maka $H_{0}$ diterima

\section{Koefisien Determinasi $\left(R^{2}\right)$}

Koefisien determinasi digunakan untuk mengetahui kecocokan atau ketepatam suatu model. Nilai koefisien deterninasi yaitu antara 0 sampai dengan 1 dimana jika nilai $R^{2}$ makin mendekati 1 maka pengaruh variabel bebas $X$ terhadap variabel tidak bebas $Y$ semakin besar. Pada persamaan (6) ditunjukkan formula untuk menghitung koefisien determinasi dan Tabel 1 menunjukkan tipe hubungan antar variabel

$$
R^{2}=1-\frac{(n-k-1) S_{y .12 \ldots k}^{2}}{(n-1) S_{y}^{2}}
$$

dimana:

$R^{2}=$ koefisien determinasi

$S_{y}=$ standar deviasi variabel tidak bebas $Y$

$n$ = banyak sampel 
Tabel 1. Interpretasi Koefisien

\begin{tabular}{|c|c|}
\hline Interval Koefisien & Tingkat Hubungan \\
\hline $0,00-0,199$ & Sangat Rendah \\
\hline $0,20-0,399$ & Rendah \\
\hline $0,40-0,599$ & Cukup Kuat \\
\hline $0,60-0,799$ & Kuat \\
\hline $0,80-1,00$ & Sangat Kuat \\
\hline
\end{tabular}

\section{Uji Regresi Individual (Uji Statistik t)}

Uji ini berguna untuk mengetahui seberapa besar pengaruh satu variabel independen secara individual/parsial dalam menerangkan variasi variabel dependen. Dasar pengambilan keputusan dalam kriteria pengujian yaitu sebagai berikut:

iii. Jika $t_{\text {hitung }} \geq t_{\text {tabel }}$ maka variabel independen secara parsial ada hubungan berpengaruh terhadap variabel dependen

iv. Jika $t_{\text {hitung }}<t_{\text {tabel }}$ maka variabel independen secara parsial tidak ada hubungan berpengaruh terhadap variabel dependen

Selain itu kriteria pengujian uji-t parsial dapat menggunakan dasar pengambilan keputusan seperti di bawah ini:

i. Jika nilai signifikansi (Sig.) < 0.05 maka variabel independen secara parsial ada hubungan berpengaruh terhadap variabel dependen

ii. Jika nilai signifikansi (Sig.) $>0.05$ maka variabel independen secara parsial tidak ada hubungan berpengaruh terhadap variabel dependen

\section{HASIL DAN DISKUSI}

\section{Uji Validitas}

Guna memperoleh gambaran mengenai faktor-faktor yang mempengaruhi pemahaman konsep matematis mahasiswa dalam pembelajaran jarak jauh, digunakan instrumen kuesioner yang berupa daftar pertanyaan sebagai teknik pengumpulan data. Setiap daftar pertanyaan memiliki jawaban dalam bentuk skala likert. Pada Tabel 2 ditampilkan hasil perhitungan uji validitas dan keputusannya.

Uji validitas digunakan untuk mengetahui kesahihan instrumen kuesioner dan uji validitas menggunakan rumus korelasi Pearson Product Moment. Berdasarkan Tabel 2 diperoleh bahwa seluruh item instrumen memiliki nilai $\boldsymbol{r}_{\text {hitung }}>\boldsymbol{r}_{\boldsymbol{t a b e l}}$ maka dapat dikatakan bahwa seluruh item pertanyaan dinyatakan valid. 
Tabel 2. Hasil Uji Validitas

\begin{tabular}{|c|c|c|c|}
\hline Item & $\boldsymbol{r}_{\text {hitung }}$ & $\boldsymbol{r}_{\text {tabel }}$ & Keterangan \\
\hline M1 & 0,674 & 0,121 & Valid \\
\hline M2 & 0,650 & 0,121 & Valid \\
\hline M3 & 0,736 & 0,121 & Valid \\
\hline M4 & 0,748 & 0,121 & Valid \\
\hline M5 & 0,516 & 0,121 & Valid \\
\hline M6 & 0,697 & 0,121 & Valid \\
\hline M7 & 0,698 & 0,121 & Valid \\
\hline M8 & 0,756 & 0,121 & Valid \\
\hline M9 & 0,783 & 0,121 & Valid \\
\hline M10 & 0,630 & 0,121 & Valid \\
\hline
\end{tabular}

\begin{tabular}{|c|c|c|c|}
\hline Item & $\boldsymbol{r}_{\text {hitung }}$ & $\boldsymbol{r}_{\text {tabel }}$ & Keterangan \\
\hline PD1 & 0,582 & 0,121 & Valid \\
\hline PD2 & 0,553 & 0,121 & Valid \\
\hline PD3 & 0,490 & 0,121 & Valid \\
\hline PD4 & 0,508 & 0,121 & Valid \\
\hline PD5 & 0,641 & 0,121 & Valid \\
\hline PD6 & 0,370 & 0,121 & Valid \\
\hline PD7 & 0,601 & 0,121 & Valid \\
\hline PD8 & 0,484 & 0,121 & Valid \\
\hline PD9 & 0,579 & 0,121 & Valid \\
\hline PD10 & 0,593 & 0,121 & Valid \\
\hline
\end{tabular}

\begin{tabular}{|c|c|c|c|}
\hline Item & $\boldsymbol{r}_{\text {hitung }}$ & $\boldsymbol{r}_{\text {tabel }}$ & Keterangan \\
\hline F1 & 0,717 & 0,121 & Valid \\
\hline F2 & 0,756 & 0,121 & Valid \\
\hline F3 & 0,721 & 0,121 & Valid \\
\hline F4 & 0,737 & 0,121 & Valid \\
\hline F5 & 0,695 & 0,121 & Valid \\
\hline F6 & 0,720 & 0,121 & Valid \\
\hline F7 & 0,709 & 0,121 & Valid \\
\hline F8 & 0,698 & 0,121 & Valid \\
\hline F9 & 0,758 & 0,121 & Valid \\
\hline F10 & 0,746 & 0,121 & Valid \\
\hline
\end{tabular}

\begin{tabular}{|c|c|c|c|}
\hline Item & $\boldsymbol{r}_{\text {hitung }}$ & $\boldsymbol{r}_{\text {tabel }}$ & Keterangan \\
\hline LK1 & 0,542 & 0,121 & Valid \\
\hline LK2 & 0,734 & 0,121 & Valid \\
\hline LK3 & 0,745 & 0,121 & Valid \\
\hline LK4 & 0,617 & 0,121 & Valid \\
\hline LK5 & 0,634 & 0,121 & Valid \\
\hline LK6 & 0,498 & 0,121 & Valid \\
\hline LK7 & 0,369 & 0,121 & Valid \\
\hline LK8 & 0,276 & 0,121 & Valid \\
\hline LK9 & 0,475 & 0,121 & Valid \\
\hline LK10 & 0,326 & 0,121 & Valid \\
\hline
\end{tabular}

Keterangan:

$\mathrm{M}_{\mathrm{i}} \quad$ : Item Motivasi ke $-\mathrm{i}$

$\mathrm{PD}_{\mathrm{i}} \quad$ : Item Peran Dosen ke - i

$\mathrm{F}_{\mathrm{i}} \quad$ : Item Fasilitas ke - i

$\mathrm{LK}_{\mathrm{i}} \quad$ : Item Lingkungan Keluarga ke - i

\section{Uji Reliabilitas}

Uji reliabilitas digunakan untuk menghitung keakuratan instrumen. Pada Tabel 3 ditunjukkan hasil uji reliabilitas untuk masing-masing variabel motivasi, peran dosen, fasilitas dan lingkungan keluarga. Berdasarkan hasil perhitungan, untuk seluruh variabel memiliki nilai Cronbach's Alpha lebih besar dari 0,6 yang artinya instrumen variabel motivasi, peran dosen, fasilitas dan lingkungan 
keluarga dapat dikatakan reliabel.

Tabel 3. Hasil Uji Reliabilitas

\begin{tabular}{|c|c|}
\hline Variabel & Cronbach's Alpha \\
\hline Motivasi & 0,804 \\
\hline Peran Dosen & 0,674 \\
\hline Fasilitas & 0,769 \\
\hline Lingkungan Keluarga & 0,673 \\
\hline
\end{tabular}

\section{Uji Normalitas}

Uji Normalitas digunakan untuk menguji apakah nilai residual yang dihasilkan dari regresi terdistribusi normal. Jika model regresi memiliki nilai residual terdistribusi normal maka dapat dikatakan model regresi yang diperoleh baik. Pada Gambar 2 grafik Normal Q-Q menunjukkan bahwa titik-titik data berada disekitar garis lurus maka nilai residual yang dihasilkan regresi terdistribusi normal, sehingga dapat dikatakan model regresi memenuhi asumsi normalitas.
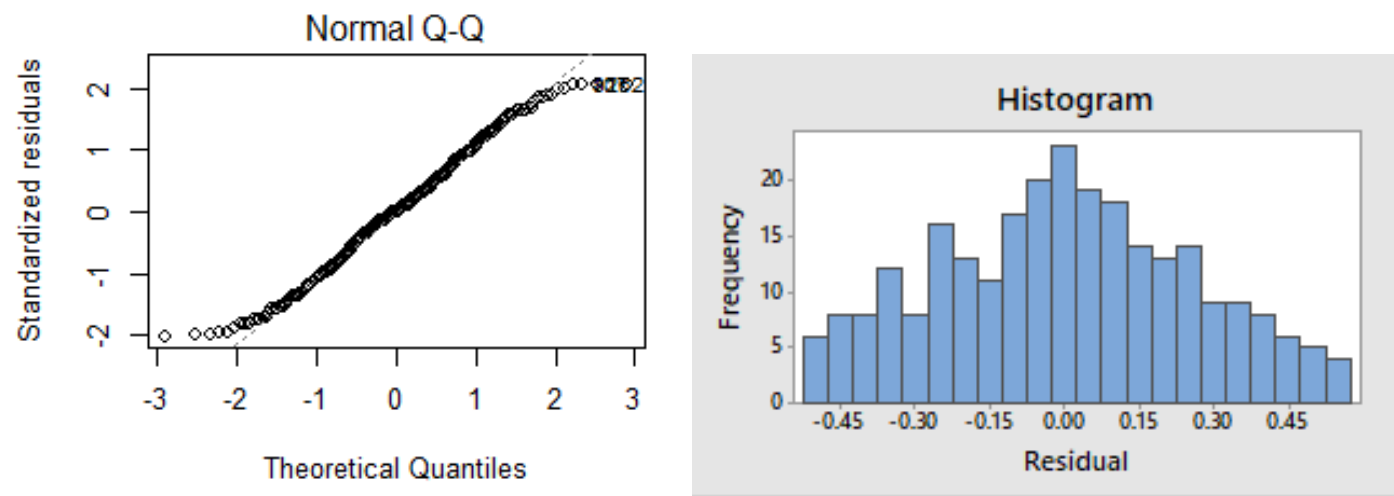

Gambar 2. Grafik Data Terdistribusi Normal

Selain itu berdasarkan Tabel 4 hasil dari uji normalitas diperoleh nilai signifikansi Asymp.Sig (2-tailed) yaitu 0.200 lebih besar dari 0.05 maka sesuai dengan dasar pengambilan keputusan dalam uji normalitas kolmogorov-smirnov dapat dikatakan bahwa data berdistribusi normal sehingga asumsi atau persyaratan normalitas dalam model regresi sudah terpenuhi.

Tabel 4. Uji Normalitas

\section{One-Sample Kolmogorov-Smirnov Test}

\begin{tabular}{llr} 
& & Unstandardized Residual \\
\hline $\mathrm{N}$ & & 262 \\
\cline { 2 - 3 } Normal Parameters ${ }^{\mathrm{a}, \mathrm{b}}$ & Mean & .0000000 \\
\cline { 2 - 3 } & Std. Deviation & .25812834 \\
\hline Most Extreme Differences & Absolute & .033 \\
\cline { 2 - 3 } & Positive & .033 \\
\cline { 2 - 3 } & Negative & -.029 \\
\hline Test Statistic & & .033 \\
\hline Asymp. Sig. (2-tailed) & & .200 \\
\hline
\end{tabular}

a. Test distribution is Normal 


\section{Uji Multikolinearitas}

Uji Multikolinearitas digunakan untuk menguji apakah terdapat korelasi atau hubungan antar variabel independen dalam model regresi. Pengujian multikolinearitas dilakukan dengan melihat IVF. Berikut ini hasil dari uji multikolinearitas yang ditunjukkan pada Gambar 3:

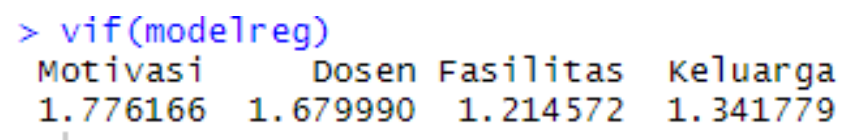

Gambar 3. Hasil Uji Multikolinearitas

Berdasarkan Gambar 3 diperoleh nilai IVF untuk variabel Motivasi, Peran Dosen, Fasilitas dan Peran Keluarga berada di bawah 10 maka tidak terjadi multikolinearitas, sehingga dapat dikatakan model regresi memenuhi asumsi multikolinearitas.

\section{Uji Heteroskedastisitas}

Uji Heteroskedastisitas digunakan untuk menguji model regresi apakah memiliki ketidaksamaan varians dari pengamatan satu ke pengamatan yang lain. Pada Gambar 4 ditunjukkan hasil uji heteroskedastisitas. Berdasarkan Gambar 4 bahwa titik-titik data tersebar dan tidak membentuk pola tertentu maka tidak terjadi perbedaan varians residual, sehingga dapat dikatakan model regresi memenuhi uji asumsi heteroskedastisitas.

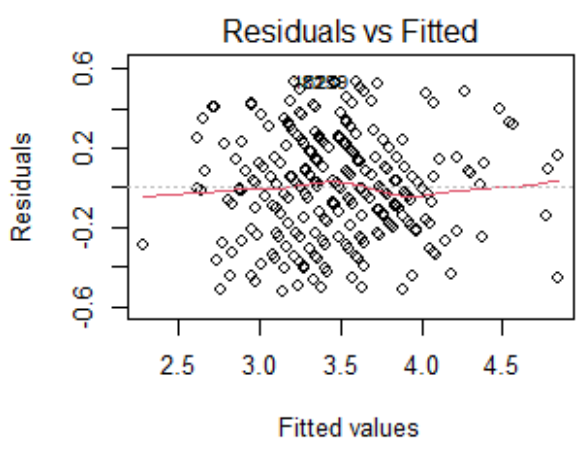

Gambar 4. Uji Heteroskedastisitas

\section{Uji Autokorelasi}

Uji Autokorelasi digunakan untuk menguji apakah terdapat pengaruh antar data terdahulu dengan data yang baru. Uji autokorelasi menggunakan test Durbin Watson dan hasil uji autokorelasi ditunjukkan pada Gambar 5 di bawah ini. Berdasarkan Gambar 5 diperoleh p-value lebih dari 0.05 maka tidak terjadi pengaruh antar data terdahulu dengan data yang baru, sehingga dapat dikatakan asumsi tidak ada autokorelasi antar data pada model regresi terpenuhi.

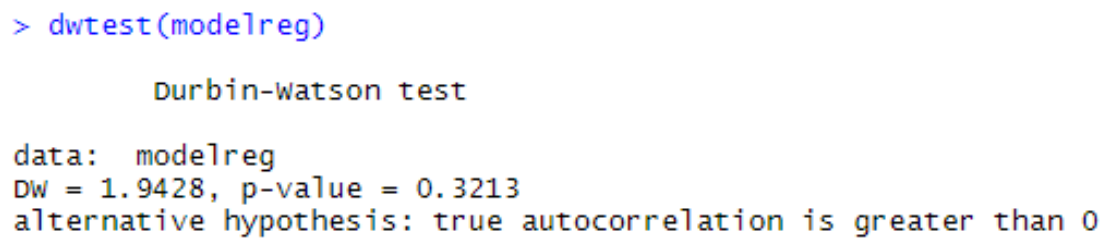


Gambar 5. Uji Autokorelasi

\section{Analisis Regresi Linear Berganda}

Analisis ini digunakan untuk mengetahui apakah terdapat pengaruh antara motivasi, peran dosen, fasilitas dan lingkungan keluarga terhadap pemahaman konsep matematis mahasiswa. Hasil analisis ditunjukkan pada Gambar 6, sehingga persamaan regresi dapat ditulis pada persamaan (7)

$$
\widehat{Y}=0.1833+0.7746 X_{1}+0.1443 X_{2}+0.0882 X_{3}+0.0768 X_{4}
$$

Dari persamaan (7) dapat dikatakan jika variabel motivasi $\left(X_{1}\right)$, peran dosen $\left(X_{2}\right)$, fasilitas $\left(X_{3}\right)$, dan lingkungan keluarga $\left(X_{4}\right)$ bernilai 0 maka nilai pemahaman konsep yaitu 0.1833 sebagai nilai konstanta. Koefisien regresi variabel $X_{1}$ sebesar 0.7746 menunjukkan jika variabel lainnya bernilai tetap dan motivasi $\left(X_{1}\right)$ mengalami kenaikan $1 \%$ maka pemahaman konsep matematis $(\mathrm{Y})$ akan mengalami kenaikan sebesar 0.7746. Untuk koefisen variabel $X_{2}$ sebesar 0.1443 menunjukkan jika variabel lainnya tetap dan peran dosen $\left(X_{2}\right)$ mengalami kenaikan $1 \%$ makan nilai $\mathrm{Y}$ akan mengalami kenaikan sebesar 0.1443. Begitu juga untuk koefisien fasilitas $\left(X_{3}\right)$ dan lingkungan keluarga $\left(X_{4}\right)$. Pada variabel motivasi $\left(X_{1}\right)$, peran dosen $\left(X_{2}\right)$, fasilitas $\left(X_{3}\right)$ dan lingkungan keluarga $\left(X_{4}\right)$ terjadi hubungan positif karena memiliki koefisien yang positif.

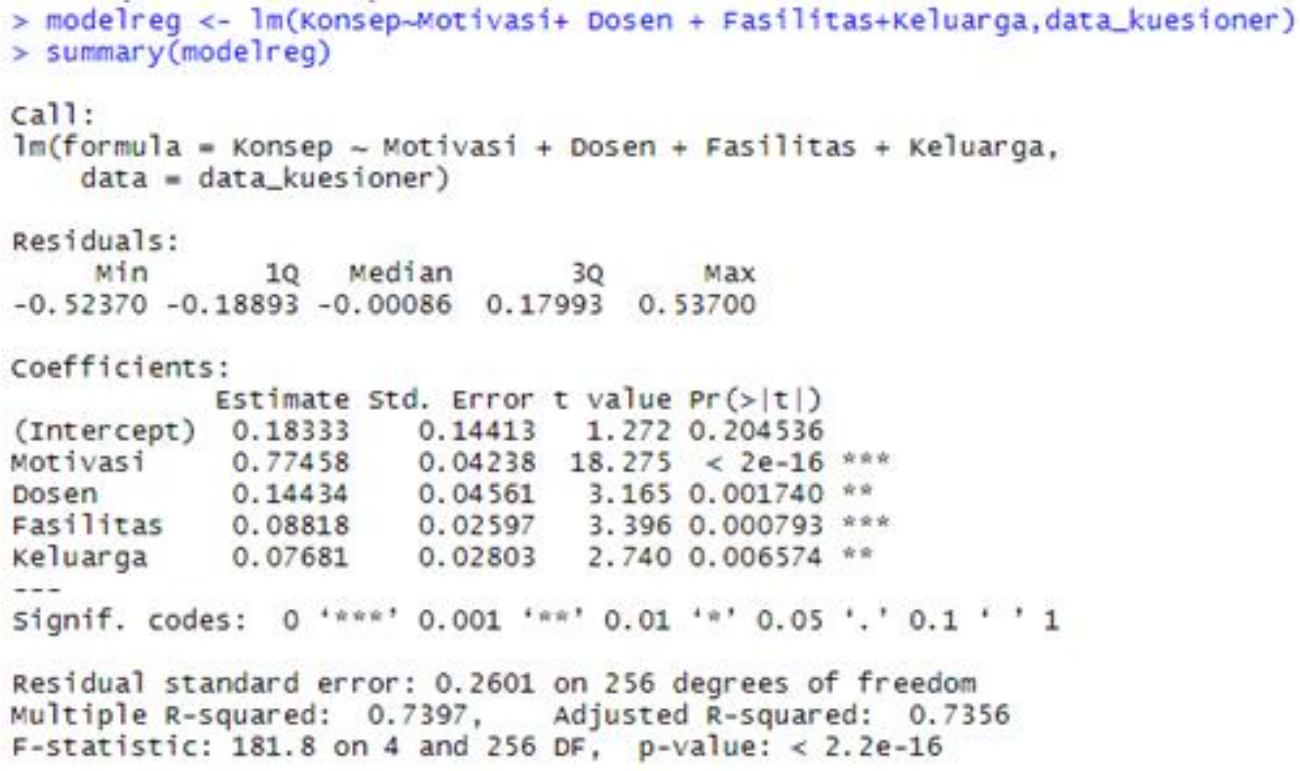

Gambar 6. Analisis Regresi Berganda

\section{Uji F pada Regresi Linear Berganda}

Uji F digunakan untuk menguji pengaruh variabel independen (motivasi, peran dosen, fasilitas dan lingkungan keluarga) secara simultan terhadap variabel dependen (pemahaman konsep matematis). Berikut ini pada Tabel 5 ditampilkan hasil olah data dengan uji F: 


\section{Tabel 5. Uji F}

ANOVA $^{\mathrm{a}}$

\begin{tabular}{|l|l|r|r|r|r|c|}
\hline \multicolumn{2}{|l|}{ Model } & Sum of Squares & df & Mean Square & F & Sig. \\
\hline \multirow{3}{*}{1} & Regression & 49.219 & 4 & 12.305 & 181.832 & $.000^{\mathrm{b}}$ \\
\cline { 2 - 7 } & Residual & 17.324 & 256 & .068 & & \\
\cline { 2 - 7 } & Total & 66.543 & 260 & & & \\
\hline
\end{tabular}

a. Dependent Variable: Konsep (Y)

b. Predictors: (Constant), Lingkungan Keluarga (X4), Fasilitas (X3), Peran Dosen (X2), Motivasi (X1)

Berdasarkan Gambar pada tabel output ANOVA diperoleh nilai signifikansi (Sig.) dalam Uji F yaitu 0.000 . Oleh karena nilai signifikansi $(0.000)<0.05$ maka artinya variabel motivasi, peran dosen, fasilitas dan lingkungan keluarga secara simultan berpengaruh terhadap pemahaman konsep matematis mahasiswa atau berarti signifikan.

\section{Koefisien Determinasi $\left(R^{2}\right)$}

Sebelumnya telah dilakukan analisis bahwa variabel independen dalam penelitian ini yaitu motivasi, peran dosen, fasilitas dan lingkungan keluarga secara simultan berpengaruh terhadap variabel dependen yaitu pemahaman konsep matematis mahasiswa, sehingga persyaratan dalam memaknai nilai koefisien determinasi dalam analisis regresi linear berganda terpenuhi. Selanjutnya dilakukan analisis koefisien determinasi atau R Square untuk melihat seberapa besar pengaruh variabel independen secara simultan terhadap variabel dependen. Berdasarkan Tabel 6 diperoleh nilai R Square sebesar 0.74 atau $74 \%$ artinya variabel motivasi $\left(X_{1}\right)$, peran dosen $\left(X_{2}\right)$, fasilitas $\left(X_{3}\right)$, dan lingkungan keluarga $\left(X_{4}\right)$ secara simultan (bersama-sama) berpengaruh terhadap pemahaman konsep matematis (Y) sebesar 74\% maka dapat dikatakan pengaruh hubungannya kuat (lihat Tabel 1). Sedangkan sisa $26 \%$ dapat dijelaskan oleh faktor atau variabel lain yang tidak diteliti dalam penelitian ini.

Tabel 6. Nilai Koefisien Determinasi

Model Summary

\begin{tabular}{|l|c|r|r|r|}
\hline Model & R & R Square & $\begin{array}{c}\text { Adjusted R } \\
\text { Square }\end{array}$ & $\begin{array}{c}\text { Std. Error of } \\
\text { the Estimate }\end{array}$ \\
\hline 1 & $.860^{\mathrm{a}}$ & .740 & .736 & .26014 \\
\hline
\end{tabular}

a. Predictors: (Constant), Lingkungan Keluarga (X4), Fasilitas

(X3), Peran Dosen (X2), Motivasi (X1)

\section{Uji-t}

Uji-t bertujuan untuk mengetahui apakah ada pengaruh variabel bebas motivasi $\left(X_{1}\right)$, peran dosen $\left(X_{2}\right)$, fasilitas $\left(X_{3}\right)$, dan lingkungan keluarga $\left(X_{4}\right)$ secara parsial terhadap pemahaman konsep matematis $(\mathrm{Y})$. 
Tabel 7. Uji-t

\section{Coefficients $^{\mathrm{a}}$}

\begin{tabular}{|c|c|c|c|c|c|c|}
\hline & & Unstandardized & Coefficients & $\begin{array}{c}\text { Standardized } \\
\text { Coefficients }\end{array}$ & & \\
\hline & & B & Std. Error & Beta & $\mathrm{t}$ & Sig. \\
\hline$\overline{1}$ & (Constant) & .183 & .144 & & 1.272 & .205 \\
\hline & Motivasi (X1) & .775 & .042 & .777 & 18.275 & .000 \\
\hline & Peran Dosen (X2) & .144 & .046 & .131 & 3.165 & .002 \\
\hline & Fasilitas (X3) & .088 & .026 & .119 & 3.396 & .001 \\
\hline & $\begin{array}{l}\text { Lingkungan Keluarga } \\
\text { (X4) }\end{array}$ & .077 & .028 & .101 & 2.740 & .006 \\
\hline
\end{tabular}

a. Dependent Variable: Konsep (Y)

Selanjutnya di bawah ini adalah pengambilan keputusan dari setiap variabel independen dengan menggunakan hasil uji-t pada Tabel 7.

a. Variabel Motivasi $\left(X_{1}\right)$

$H_{0}$ : Tidak ada hubungan yang signifikan antara motivasi dengan pemahaman konsep matematis mahasiswa

$H_{1}$ : Ada hubungan yang signifikan antara motivasi dengan pemahaman konsep matematis mahasiswa

Berdasarkan output pada Tabel 7 diperoleh nilai signifikan (Sig.) pada Motivasi $\left(X_{1}\right)$ yaitu 0.000 lebih kecil dari 0.05 maka dapat dikatakan variabel motivasi berpengaruh signifikan secara parsial terhadap kemampuan pemahaman konsep matematis mahasiswa. Hal ini sejalan dengan pendapat Dimyati dan Mudjiono (2002) bahwa motivasi belajar merupakan kekuatan mental dalam diri individu yang mampu mendorong terjadinya proses belajar. Motivasi memiliki peran yang sangat penting dalam proses pembelajaran. Tingginya motivasi yang dimiliki mahasiswa akan menyebabkan keinginan untuk belajar tinggi sehigga mengakibatkan kemampuan pemahaman konsep matematis yang juga tinggi. Karena pemahaman konsep matematis bukan hanya mengingat fakta namun kemampuan dalam mendefinisikan, mengelompokkan, menafsirkan kembali dan mengembangkan makna arti dari sebuah konsep (Sanjaya, 2008).

b. Variabel Peran Dosen $\left(X_{2}\right)$

$H_{0}$ : Tidak ada hubungan yang signifikan antara peran dosen dengan pemahaman konsep matematis mahasiswa

$H_{1}$ : Ada hubungan yang signifikan antara peran dosen dengan pemahaman konsep matematis 
mahasiswa

Berdasarkan output pada Tabel 7 diperoleh nilai signifikan (Sig.) pada Peran Dosen $\left(X_{2}\right)$ yaitu 0.002 lebih kecil dari 0.05 maka dapat dikatakan variabel peran dosen berpengaruh signifikan secara parsial terhadap kemampuan pemahaman konsep matematis mahasiswa. Pendidik atau peran dosen dalam proses pembelajaran memiliki peran yang utama. Hal ini sesuai dengan teori yang dikemukakan oleh Djamarah bahwa jika peserta didik merasa nyaman dengan pendidik serta peserta didik memiliki suatu ketertarikan maka motivasi belajar peserta didik akan optimal dalam proses pembelajaran (Djamarah, 2002). Oleh karena itu peran pendidik atau dosen sangat menentukan dalam mempengaruhi kemampuan pemahaman konsep matematis mahasiswa dalam pembelajaran jarak jauh. Dosen sebagai motivator mampu membangkitkan semangat mahasiswa dalam proses pembelajaran serta mampu membentuk lingkungan belajar yang positif sehingga mahasiswa merasa tertarik dalam mengikuti pembelajaran.

c. Variabel Fasilitas $\left(X_{3}\right)$

$H_{0}$ : Tidak ada hubungan yang signifikan antara fasilitas dengan pemahaman konsep matematis mahasiswa

$H_{1}$ : Ada hubungan yang signifikan antara fasilitas dengan pemahaman konsep matematis mahasiswa

Berdasarkan output pada Tabel 7 diperoleh nilai signifikan (Sig.) pada Fasilitas $\left(X_{3}\right)$ yaitu 0.001 lebih kecil dari 0.05 maka dapat dikatakan variabel fasilitas berpengaruh signifikan secara parsial terhadap kemampuan pemahaman konsep matematis mahasiswa dalam pembelajaran jarak jauh. Proses belajar mengajar akan berjalan dengan baik jika sarana dan fasilitas peserta didik memadai (Suryosubroto, 2009). Pada proses pembelajaran jarak jauh adanya sinyal internet yang stabil dan perangkat elektronik seperti laptop/hp yang memadai sangat dibutuhkan untuk menunjang pembelajaran. Hal ini pun sejalan dengan yang dikemukakan oleh Sopiatin (2010) bahwa fasilitas belajar yang dimiliki oleh mahasiswa memiliki pengaruh terhadap motivasi belajar peserta didik dimana semakin baik fasilitas yang dimiliki oleh mahasiswa maka motivasi belajar mahasiswa akan semakin tinggi.

d. Variabel lingkungan keluarga $\left(X_{4}\right)$

$H_{0}$ : Tidak ada hubungan yang signifikan antara lingkungan keluarga dengan pemahaman konsep matematis mahasiswa

$H_{1}$ : Ada hubungan yang signifikan antara lingkungan keluarga dengan pemahaman konsep matematis mahasiswa

Berdasarkan output pada Tabel 7 diperoleh nilai signifikan (Sig.) pada Lingkungan Keluarga $\left(X_{4}\right)$ yaitu 0.006 lebih kecil dari 0.05 maka dapat dikatakan variabel lingkungan keluarga 
berpengaruh signifikan secara parsial terhadap kemampuan pemahaman konsep matematis mahasiswa dalam pembelajaran jarak jauh. Lingkungan keluarga memiliki peran penting dalam perkembangan peserta didik karena keluarga merupakan lingkungan sosial pertama dimana kehidupan peserta didik dimulai sehingga cara orang tua mendidik, relasi antar anggota keluarga, ekonomi keluarga, suasana rumah dan latar belakang berpengaruh terhadap gaya belajar mahasiswa (Syah, 2010). Keberhasilan orang tua dalam mendidik di rumah akan memberikan respon yang positif dan meningkatkan motivasi mahasiswa dalam proses pembelajaran. Pada masa pandemi covid-19 ini, mahasiswa melakukan PJJ dari rumah masing-masing sehingga pengarahan dan pengawasan yang dilakukan oleh orang tua serta suasana keluarga akan memberikan kontribusi untuk motivasi belajar mahasiswa yang juga akan mempengaruhi pemahaman konsep matematis.

\section{KESIMPULAN}

Penelitian ini bertujuan untuk mengetahui faktor-faktor yang berpengaruh signifikan terhadap kemampuan pemahaman konsep matematis mahasiswa dalam pembelajaran jarak jauh pada masa pandemi Covid-19. Ditinjau dari uji-t parsial diperoleh kesimpulan bahwa motivasi, peran dosen, fasilitas dan lingkungan keluarga secara parsial berpengaruh signifikan terhadap kemampuan pemahaman konsep matematis mahasiswa. Faktor intrinsik atau faktor dalam yang mempengaruhi pemahaman konsep adalah motivasi belajar. Seiring dengan meningkatnya motivasi mahasiswa terhadap pembelajaran maka keberhasilan dalam mencapai tujuan pembelajaran juga akan tinggi. Motivasi yang baik adalah motivasi yang berasal dari dalam diri individu, sehingga perlu diciptakan lingkungan belajar online yang menarik dan kondusif.

Dalam menciptakan suasana yang menarik dan kondusif terdapat beberapa faktor ekstrinsik atau faktor luar yang mempengaruhi pemahaman konsep matematis mahasiswa seperti peran dosen, fasilitas dan lingkungan keluarga. Oleh karena itu, hal yang perlu diperhatikan oleh dosen sebagai pendidik diantaranya yaitu komunikasi dalam pembelajaran jarak jauh, materi yang dikemas secara menarik dan pengawasan mahasiswa oleh dosen pada saat PJJ berlangsung dan juga saat ujian. Selain itu kemahiran dalam menggunakan teknologi digital/aplikasi yang digunakan oleh dosen saat PJJ merupakan hal penting yang perlu diperhatikan oleh pendidik dalam membangun pemahaman konsep matematis mahasiswa. Saat ini mahasiswa memiliki fasilitas yang memadai dalam melaksanakan PJJ, namun tantangan yang dihadapi adalah lemahnya sinyal yang mengganggu proses pembelajaran dan cukup mahalnya biaya kuota internet. Dari faktor lingkungan keluarga, orang tua atau anggota keluarga lainnya diharapkan bisa membantu dalam menerapkan kedisiplinan belajar di rumah terhadap peserta didik serta menjaga ketentraman keluarga agar suasana belajar online berlangsung kondusif. 
Hasil analisa statistik juga menunjukkan bahwa motivasi, peran dosen, fasilitas, dan lingkungan keluarga secara bersama-sama berpengaruh terhadap kemampuan pemahaman konsep matematis. Dan model analisis regresi linear berganda yang dihasilkan yaitu sebagai berikut:

$$
\widehat{Y}=0.1833+0.7746 X_{1}+0.1443 X_{2}+0.0882 X_{3}+0.0768 X_{4}
$$

Dari model pada persamaan (8) tersebut diperoleh nilai R Square sebesar $74 \%$ yang artinya variabel independen (motivasi, peran dosen, fasilitas, dan lingkungan keluarga) secara simultan berpengaruh terhadap variabel dependen (pemahaman konsep matematis) sebesar 74\%. Terdapat sisa $26 \%$ yang dipengaruhi oleh faktor atau variabel lain yang tidak diteliti dalam penelitian ini. Oleh karena itu, peneliti berharap untuk penelitian selanjutnya dapat menambahkan variabel-variabel lain seperti model pembelajaran daring yang digunakan oleh pendidik, gaya belajar mahasiswa, kecerdasan latihan, lingkungan sosial (selain keluarga), lembar kerja siswa yang diberikan oleh pendidik, dan lain-lain yang memiliki peluang dalam mempengaruhi pemahaman konsep matematis mahasiswa.

\section{UCAPAN TERIMA KASIH}

Dalam penelitian ini peneliti menyadari bahwa tanpa bantuan dukungan dari berbagai pihak penelitian ini tidak dapat terselesaikan dengan baik. Oleh sebab itu, dalam kesempatan ini peneliti secara khusus megucapkan terima kasih kepada seluruh dosen serta mahasiswa di wilayah Jabodetabek dan seluruh pihak yang telah membantu dalam pelaksanaan kegiatan ini sehingga berjalan dengan baik dan lancar.

\section{REFERENSI}

Djamarah, B. S. (2002). Psikologi Belajar. Jakarta: PT Rineka Cipta

Dimyati dan Mudjiono. (2002). Belajar dan Pembelajaran. Jakarta: Rineka Cipta

Ghozali, I. (2011). Aplikasi Analisis Multivariate dengan Program IBM SPSS 19. Semarang: Penerbit UNDIP

Hendriana, H., et.al. (2017). Hard skills dan Soft Skills Matematik Siswa. Bandung: PT Refika Aditama.

Kementerian Pendidikan dan Kebudayaan Republik Indonesia. (2020). Surat Edaran No.4 Tahun 2020 tentang Pelaksanaan Kebijakan Pendidikan dalam Masa Darurat Penyebaran Corona Virus Disease (Covid-19)

Kusuma, J.W. (2016). Pengaruh Pembelajaran Think Talk Write (TTW) Terhadap Hasil Belajar Mahasiswa STIE Bina Bangsa Pada Mata Kuliah Matematika Ekonomi. Matematika Jurnal Volume III No.2, ISSN: 2355-3782

Moore, J.L., Dickson-Deane, C., \& Galyen, K. (2011). E-Learning, online learning, and distance learning environments: Are they same? Internet and Higher Education. https://doi.org/10.1016/j.iheduc.2010.10.001 
Analisis Faktor-Faktor yang Mempengaruhi Pemahaman Konsep Matematis Mahasiswa dalam Pembelajaran Jarak

National Council of Teacher of Mathematics. (2000). Principles And Standards For School Mathematics. Reston, VA: NCTM

Purwanto, A., et.al. (2020). Studi Eksploratif Dampak Pandemi Covid-19 Terhadap Proses

Pembelajaran Online di Sekolah Dasar. Journal of Education, Psychology and Counseling Volume 2 Nomor 1, ISSN Online: 2716-4446

Purwanto, N. (2007). Psikologi Pendidikan. Bandung: PT Remaja Rosdakarya.

Sadikin, A. \& Hamidah, A. (2020). Pembelajaran Daring di Tengah Wabah Covid-19. BIODIK: Jurnal Ilmiah Pendidikan Biologi Volume 6, Nomor 02, 214-224

Sanjaya, W. (2008). Perencanaan dan Desain Sistem Pembelajaran. Jakarta: Prenada Media Group Sopiatin, P. (2010). Manajemen Belajar Berbasis Kepuasan Siswa. Bogor: Ghalia Indonesia.

Sudjana. (2005). Metode Statistika. Bandung: Tarsito.

Suharjo, B. (2008). Analisis Regresi Terapan dengan SPSS. Yogyakarta: Graha Ilmu

Sun, P.C. et.al. (2008). What Drives a Successful e-Learning? An Empirical Investigation of The Critical Factors Influencing Learner Satisfaction. Computers \& Education, Vol. 50 Issue 4, pp. 1183-1202, https://doi.org/10.1016/j.compedu.2006.11.007

Supranto, J. 2016. Statistik: Teori \& Aplikasi. Jakarta: Erlangga

Suryosubroto, B. (2009). Proses Belajar Mengajar di Sekolah. Jakarta: Rineka Cipta.

Syah, M. (2010). Psikologi Pendidikan Dengan Pendekatan Baru. Bandung: PT. Remaja Rosada Karya.

Umar, H. (2007). Riset Sumber Daya Manusia dalam Organisasi Publik dan Bisnis. Bandung: Alfabeta.

Zhao, F. (2003). Enhancing The Quality of Online Higher Education. Quality Assurance in Education, Vol. 11 No 4, pp. 214-221. https://doi.org/10.1108/09684880310501395 